\title{
Akuntansi dalam Rumah Tangga : Study Fenomenologi pada Akuntan dan Non Akuntan
}

\author{
Melia Yulianti ${ }^{1}$ \\ 1Jurusan Akuntansi, Politeknik Negeri Padang \\ Email:melia.yulianti@gmail.com
}

\begin{abstract}
Some people or couples in the household who are responsible for household finances. This research was conducted by comparing qualitative in accounting aspects investigated by motivation, benefits and values developed in household accounting practices as well as budgeting, recording, decision making and long-term financial planning. Data was collected through semi structured interview collection. As informants who were made the object of this study were household partners who work as accountants and non accountants. Furthermore, the research findings were analyzed by discussing the theme, with mental accounting as the theoretical agreement. The results of the study show how accounting practices in the families of accountant and non-accountant families vary where not only the background of education but also related to employment, non-geographical and mental status needed by couples in practicing accounting in the household. for household partners in managing household finances.

Keywords: Household Accounting, Phenomenology, Mental Accounting, Accountants and Non Accountants
\end{abstract}

\begin{abstract}
Abstrak
Beberapa individu atau pasangan dalam rumah tangga memerlukan akuntansi rumah tangga untuk mengelola keuangan. Penelitian ini dilakukan dengan pendekatan kualitatif dimana aspek-aspek akuntansi yang diinvestigasi adalah motivasi, manfaat dan nilai-nilai yang lahir dalam praktik akuntansi rumah tangga serta penganggaran, pencatatan, pengambilan keputusan dan perencanaan keuangan jangka panjang. Data penelitan dikumpulkan melalui serangkaian wawancara semi terstrukstur. Adapun Informan yang dijadikan objek dalam penelitian ini merupakan pasangan rumah tangga yang berprofesi sebagai akuntan dan non akuntan. Lebih lanjut temuan penelitian dianalisis dengan pendekatan analisis tema, dengan mental accounting sebagai kerangka teori. Hasil penelitian menunjukkan bahwa praktik akuntansi dalam rumah tangga keluarga akuntan dan non akuntan bervariasi dimana tidak hanya dilatarbelakangi oleh pendidikan namun juga disebabkan oleh status pekerjaan, unsur geografis dan mental yang dimiliki oleh pasangan dalam mempraktikkan akuntansi dalam rumah tangga. Implikasi dari penelitian ini diharapkan menjadi acuan awal bagi pasangan rumah tangga dalam mengelola keuangan rumah tangga.
\end{abstract}

Kata kunci: Akuntansi Rumah Tangga, Fenomenologi, Mental accounting, Akuntan dan Non Akuntan

\section{Pendahuluan}

Uang digunakan sebagai alat tukar untuk memenuhi kebutuhan sandang, pangan dan papan. Kebutuhan manusia terhadap uang semakin meningkat seiring dengan meningkatnya kompleksitas pemenuhan kebutuhan hidup. Demikian juga halnya 
kebutuhan manusia semakin kompleks ketika telah berumah tangga.

Sejalan dengan hal tersebut, kebutuhan dalam rumah tangga tidak terbatas. Hal itu dibuktikan dengan adanya pemenuhan kebutuhan hidup sehari-hari yang pada awalnya untuk individual, berkembang untuk keluarga, kemudian pemenuhan kebutuhan pendidikan anak-anak, pemenuhan kebutuhan asuransi kesehatan, pemenuhan kebutuhan dana pensiun untuk dihari tua dan yang lainnya. Kompleksnya kebutuhan di dalam rumah tangga menuntut pasangan suami-istri harus cerdas menyikapi pendapatan dan pengeluaran keuangannya. Kemampuan mengelola keuangan sangat mutlak dan penting dimiliki dalam menyikapi dan mengelola keuangan di dalam rumah tangga. Sebaliknya, ketidakmampuan dalam mengelola keuangan di dalam rumah tangga dapat berdampak pada terganggunya keharmonisan dalam keluarga.

Seiring dengan perkembangan tingkat kebutuhan di dalam rumah tangga, keberadaan akuntansi adalah suatu keniscayaan. Meskipun banyak orang berpendapat bahwa akuntansi hanya dipraktikkan dalam entitas bisnis saja, pada dasarnya pengelolaan keuangan di dalam rumah tangga mencerminkan praktikpraktik dan nilai-nilai yang tercermin dalam akuntansi, seperti transparancy dan responsibility. Lemahnya pengelolaan keuangan dalam rumah tangga menimbulkan permasalahan yang rumit dibandingkan permasalahan sex, (Gundrey, 1975; Allen, 1977 dalam Walker, 2000) dimana hal tersebut diyakini berisiko menyebabkan kehilangan teman-teman terdekat dan terjadinya perceraian di dalam rumah tangga (Philips dan Lane, 1980 dalam Manurung dan Sinton, 2013).

Berdasarkan dengan pernyataan di atas, data dari pengadilan agama di salah satu kota di Indonesia, yaitu Probolinggo, menunjukkan bahwa angka perceraian dari tahun ke tahun terus mengalami peningkatan. Pengadilan Agama mencatat selama lima tahun terakhir (tahun 2007 sampai tahun 2013) terjadi sebanyak 1670 kasus perceraian. Rata- rata faktor penyebab terjadinya perceraian tersebut didominasi karena masalah ekonomi, kurang tanggung jawab dan kurangnya keharmonisan. Sebagaimana diungkapkan oleh wakil Panitera pengadilan Agama Kota Probolinggo "Faktor ekonomi, tidak harmonis dan ketidakcocokan pasangan menjadi alasan tertinggi terjadinya perceraian" (Koran Madura, 18 Februari 2014). Fenomena yang terjadi di pengadilan agama Probolinggo patut menjadi alasan bagi setiap pasangan keluarga untuk mengelola keuangannya dan menerapkan praktik-praktik akuntansi dalam kehidupan rumah tangga, mengingat konflik perceraian yang disebabkan oleh masalah ekonomi bisa terjadi pada siapa saja dan di mana saja.

Pada dasarnya, kebutuhan akan akuntansi dalam rumah tangga dibutuhkan oleh setiap pasangan. Penerapan akuntansi rumah tangga ini tidak hanya untuk pasangan keluarga akuntan namun juga dibutuhkan oleh pasangan keluarga non akuntan. Berdasarkan uraian latar belakang masalah di atas, maka penelitian ini diberi judul "Akuntansi Rumah Tangga: Study Fenomologi pada Akuntan dan Non Akuntan". Masalah yang dapat dirumuskan adalah: Bagaimana akuntansi diterapkan dalam rumah tangga akuntan dan non akuntan? 


\section{Landasan Teori}

\section{Pengertian Akuntansi}

The American Accounting Association mendefinisikan akuntansi sebagai suatu proses mengidentifikasi, mengukur, dan melaporkan informasi ekonomi untuk memungkinkan adanya penilaian dan pengambilan keputusan yang jelas dan tegas bagi mereka yang menggunakan informasi tersebut (Soemarso, 2013). Sedangkan, American Insitute Certified Public Accounting memberikan definisi akuntansi sebagai seni pencatatan, penggolongan, peringkasan yang tepat dan dinyatakan dalam satuan mata uang, transaksi-transaksi dan kejadian-kejadian yang setidak-tidaknya bersifat finansial dan penafsiran hasil-hasilnya (Sumber: www.mediaberita.net).

Meskipun pengertian akuntansi sangat melekat dengan proses pengidentifikasian, pencatatan, pelaporan dan pengambilan keputusan dalam konteks bisnis, akuntansi yang dimaksud di dalam penelitian ini tidak dibatasi oleh definisi tersebut. Hal ini dikarenakan oleh kepentingan suatu entitas berbeda dengan kepentingan dalam rumah tangga. Namun, secara garis besar pengelolaan keuangan dalam rumah tangga juga mencerminkan praktik-praktik akuntansi, seperti: pengambilan keputusan menabung untuk tujuan jangka pendek dan panjang, investasi dalam pemenuhan tujuan jangka panjang serta kebiasaan menghitung kembali pengeluaran yang telah dilakukan. Dalam konteks ilmu akuntansi modern, Roslender (1992 dalam Sukoharsono, 1998) mengatakan:

“... modern accountancy is a highly relevant subject for study at the present time. Having designated it as an institution... In this way accountancy is being seen as the equivalent of the other major social institutions such as the family, religion, work, education, art and literature, and science and technology".

Akuntansi modern merupakan kajian yang sangat relevan untuk mempelajari fenomena yang terjadi saat ini, sehingga akuntansi dapat disejajarkan dengan institusi sosial lainnya seperti keluarga, agama, pekerjaan, pendidikan, seni dan literatur serta pengetahuan dan teknologi. Ilmu akuntansi diharapkan bisa menjadi suatu bidang ilmu yang digunakan sebagai sumber pemecahan masalah. Akuntansi merupakan bidang ilmu yang mengalami kemajuan cukup pesat. Pada awalnya, akuntansi hanya digunakan oleh para pelaku bisnis sebagai sumber informasi terhadap keuntungan atau kerugian perusahaan. Akan tetapi, saat ini akuntansi tidak hanya terbatas untuk perusahaan-perusahaan saja, tetapi juga dibutuhkan oleh industri kecil, industri rumahan bahkan pada organisasi terkecil, yaitu rumah tangga.

\section{Akuntansi dalam Rumah Tangga}

Definisi akuntansi dalam rumah tangga yang diterima umum dapat dilihat dari pengertian secara bahasa, bahwa akuntansi dalam rumah tangga adalah praktikpraktik pengelolaan keuangan dalam rumah tangga dengan menggunakan aspek-aspek akuntansi. Akuntansi dalam rumah tangga sangat penting dalam mengelola pendapatan dan pengeluaran keuangan, mengingat kondisi kehidupan dan kebutuhan yang semakin kompleks menuntut setiap keluarga untuk mampu 
mempertahankan keberlangsungan kehidupannya. Akan tetapi kebanyakan individu maupun pasangan suami-istri dalam rumah tangga takut melakukan pengelolaan keuangannya. Hal itu sesuai dengan pernyataan Allen (1977, p.23 dalam Northchott dan Bill, 2000) yang mengatakan bahwa kebanyakan individu takut memperlakukan anggaran dalam rumah tangga seperti anggaran dalam perusahaan. Penelitian akuntansi dalam rumah tangga mengalami perkembangan dalam beberapa tahun terkahir. Hal itu dibuktikan dengan banyaknya peneliti luar negeri yang melakukan penelitian akuntansi dalam rumah tangga diantaranya Northcott dan Bill tahun 2000, yang melakukan penelitian dengan judul Home Accountants: exploring their practices, kemudian Carniege and walker tahun 2005 dengan judul Prescription and practice from the 1820s to the 1960s. Penelitian ini membahas empat aspek praktik akuntansi dalam rumah tangga di kehidupan sehari-hari dilihat dari sisi penganggaran, pencatatan, pengambilan keputusan dan perencanaan keuangan jangka panjang (Northcott dan Bill, 2000).

\section{a. Penganggaran}

Penganggaran merupakan hal yang penting dilakukan terlebih dalam kehidupan rumah tangga. Penganggaran adalah kegiatan mengelompokkan, memprediksi kemampuan dari pendapatan yang diperoleh untuk dialokasikan ke pengeluaran yang bermanfaat dalam pencapaian tujuan keluarga. Perencanaan penganggaran yang baik sangat diperlukan untuk memenuhi kebutuhan dimasa depan yang digunakan individu sebagai cadangan dalam mengantisipasi segala kemungkinan ketidakpastian dimasa depan. Disamping itu, pengganggaran memungkinkan individu untuk bisa menentukan kebutuhan hidup sehari-sehari baik dalam perencanaan jangka pendek maupun jangka panjang (McRae, 1997 dalam Northcott dan Bill, 2000).

Penganggaran dalam rumah tangga dilakukan dengan memilah alokasi pengeluaran seperti: pengeluaran kebutuhan dapur, pengeluaran biaya listrik, biaya pendidikan anak, tabungan dan masih banyak lainnya. Suatu pendekatan dalam penganggaran keuangan rumah tangga diperlukan untuk mengendalikan sejumlah anggaran pengeluaran dirumah tangga yang mengakibatkan adanya pembatasan atas hal- hal yang sangat urgent dikeluarkan dan yang tidak terlalu penting untuk dikeluarkan sehingga bisa melakukan penghematan pengeluaran (Thaller, 1992 dalam Northcott dan Bill, 2000).

Penganggaran mempunyai beberapa manfaat dan peran yang sangat bagus dalam kehidupan rumah tangga yaitu, untuk mengontrol pengeluaran, sebagai alaram untuk mencegah terjebak kedalam hutang dan untuk memperingatkan bahwa pendapatan jangka pendek dan pola pengeluaran selaras dengan pencapaian tujuan jangka panjang.

\section{b. Pencatatan}

Pencatatan terhadap sumber-sumber pendapatan dan pengeluaran rumah tangga merupakan tindakan yang tepat untuk melihat dan mengontrol pembayaran atau pengeluaran dalam rumah tangga. Penggunaan pencatatan akuntansi sangat baik dilakukan sehingga ibu-ibu rumah tangga dapat menimalisir 
setiap kebutuhan-kebutuhan yang diperlukan dan dapat mengetahui jumlah pengeluaran setiap harinya sehingga diketahui besarnya pengeluaran selama sebulan (McRae, 1997 dalam Northcott dan Bill, 2000). Catatan tersebut bisa dijadikan sebagai alat kontrol dan penilaian tentang kelayakan suatu pengeluaran yang digunakan. Dengan kata lain, catatan tersebut dijadikan bahan evaluasi dalam pengambilan keputusan yang tepat. Catatan akuntansi di dalam rumah tangga tidak dimaksudkan untuk mempersulit melainkan sebagai pemberi signal atau sebagai dasar pengambilan informasi.

Ada beberapa manfaat yang diperoleh dengan melakukan pencatatan terhadap pengeluaran- pengeluaran dirumah tangga diantaranya: untuk melihat kembali kemana saja uang tersebut dibelanjakan, untuk menilai boros tidaknya dalam melakukan pengeluaran. Dengan melakukan pencatatan kita bisa menjelaskan dan merinci pengeluaran berdasarkan barang dan harganya hal itu akan memberikan kepuasaan dan kenyamanan tersendiri (Allen, 1977, p. 23; Wright, 1988, p. 21 dalam Walker; 2000).

\section{c. Pengambilan Keputusan}

Setiap individu mempunyai kerangka pemikiran sendiri dalam mengambil keputusan keuangan di dalam rumah tangga dan keputusan-keputusan yang diambil harus penuh pertimbangan untuk menghindari masalah keuangan. Adanya fluktuasi ekonomi maupun fluktuasi harga menuntut setiap rumah tangga untuk cerdas dalam mengambil sikap. Kompetitifnya persaingan dalam industri membuat industri semakin kreatif untuk melakukan pemasaran dengan menawarkan diskon-diskon dan hadiah menarik tertentu. Hal itu sering menarik seseorang terlebih ibu rumah tangga yang telah memiliki anak untuk melakukan pembelian tanpa memperhitungkan manfaat barang tersebut dalam memenuhi kebutuhan.

Peran pengambilan keputusan sangat penting dalam mengelola keuangan, misalnya ketika mempunyai keuangan berlebih apakah digunakan untuk safety kedepannya seperti halnya memasukkannya kedalam tabungan, melakukan investasi atau langsung digunakan secara keseluruhan dalam memenuhi kebutuhan hidup. Pengambilan keputusan merupakan suatu sikap dengan memperhitungkan resiko yang akan dihadapi, keputusan yang diambil oleh individu sangat erat kaitannya dengan keberanian dan mental yang dimiliki oleh individu tersebut seperti halnya ketika individu dihadapkan pada pilihan untuk melakukan pinjaman atau berhutang dalam memenuhi kebutuhan atau memilih menunda sampai keuangan cukup untuk memenuhi kebutuhan tersebut.

\section{d. Perencanaan Keuangan Jangka Panjang}

Perencanaan jangka panjang merupakan bentuk kepedulian terhadap kehidupan masa depan. Perencanaan jangka panjang adalah suatu bentuk penyusunan rencana dimana manfaat dari perencanan dirasakan dalam waktu yang lama dengan implikasi pelaksanaan rencana tersebut dilakukan diawal. Ada beberapa kondisi yang mengharuskan adanya investasi dalam rumah tangga, diantaranya untuk keberlangsungan kehidupan dihari tua. Investasi di dalam rumah tangga merupakan bentuk pencadangan dalam memenuhi kebutuhan- kebutuhan dimasa mendatang. 
Penghematan dalam melakukan pengeluaran merupakan suatu bentuk perencanaan jangka panjang yang mengharuskan setiap pasangan suami-istri dalam rumah tangga mampu mengelola keuangan dalam kehidupan rumah tangganya (Manurung dan Sinton: 2013).

Seiring dengan berkembangnya perekonomian Investasi dan asuransi merupakan salah satu bentuk dari perencanaan keuangan jangka panjang. Berbagai produk investasi telah banyak disediakan oleh lembaga keuangan. Kecermatan dan ketelitian dalam memilih produk investasi akan menetukan hasil dari perencanaan jangka panjang. Dalam kehidupan rumah tangga perencanaan merupakan sesuatu yang mutlak harus dimiliki terlebih dengan hal mendatang yang tidak bisa dipastikan kejadiannya.

\section{e. Motif Penerapan Akuntansi dalam Rumah Tangga}

Akuntansi secara tidak langsung telah menjadi bagian dari pengelolaan keuangan individu dalam rumah tangga. Espa dan Triwuyono (2011) dalam penelitiannya mengatakan ada tiga hal yang mendasari dan memotivasi individu dalam menerapkan akuntansi dalam rumah tangga yaitu: untuk membentuk perilaku anggota keluarga, mempererat jalinan cinta (suami-istri) dan sebagai pertanggungjawaban kepada Allah mengenai zakat.

Secara umum ada banyak hal yang mendasari dan memotivasi individu untuk menerapkan akuntansi dalam rumah tangga salah satunya dimotivasi oleh ketidakpastian masa depan, adanya kecemasan terhadap kemampuan dalam memenuhi kehidupan dimasa depan dan karena kehidupan ekonomi yang semakin berfluktuatif.

\section{f. Manfaat Akuntansi dalam Rumah Tangga}

Dalam dunia bisnis, akuntansi merupakan bahasa bisnis yang digunakan untuk menjelaskan kondisi keuangan perusahaan. Sejalan dengan hal tersebut, akuntansi dalam rumah tanggga digunakan sebagai alat kontrol keuangan dalam rumah tangga. Manfaat akuntansi sendiri dalam kehidupan rumah tangga jika dilihat secara sederhana adalah sebagai sarana saling terbuka di antara pasangan, meningkatkan rasa tanggung jawab dan menciptakan rasa aman.

\section{g. Nilai-Nilai Akuntansi dalam Rumah Tangga}

Nilai (value) merupakan sesuatu yang biasa digunakan oleh individu untuk menilai dan mengukur kelayakan suatu tindakan. Dalam melaksanakan akuntansi dalam rumah tangga secara tidak langsung akan melatih individu untuk bertanggung jawab terhadap keuangannya, melatih individu untuk mengkomunikasikan keadaan yang sebenarnya kepada pasangannya dan melatih analisis individu dalam mengambil keputusan. Menurut Espa dan Triwuyono (2011) dalam penelitiannya menyimpulkan bahwa akuntansi dalam rumah tangga mencerminkan nilai-nilai yaitu: tanggung jawab, amanah, kejujuran, disiplin, iklhas dan rajin yang disingkat dengan sebuah kata yaitu, takdir.

Keberadaan nilai-nilai tersebut dalam rumah tangga, secara perlahan akan menjadi kebiasaan yang digunakan individu dalam bersosialisasi satu sama lainnya. Hal tersebut, akan membantu individu dalam melatih dan mengembangkan diri 
yang berdampak kepada terjalinnya hubungan baik antar sesama. Oleh karena itu, akuntansi merupakan suatu hal yang baik untuk diterapkan dalam rumah tangga.

\section{Akuntansi Rumah Tangga dalam Konteks Emosional}

Membahas akuntansi dalam rumah tangga tidak bisa lepas dari dimensi emosional karena pada dasarnya, setiap individu dalam bereaksi terhadap suatu keadaan atau kejadian di pengaruhi oleh emosi yang di miliki. Oleh karena itu, setiap keputusan yang diambil oleh masing-masing individu dalam mengelola keuangan rumah tangga berbeda-beda. Emosi diartikan sebagai hal yang dimiliki oleh individu berupa rangsangan dan reaksi terhadap suatu kejadian seperti, rasa takut, gelisah, cemas, rasa nyaman, rasa bangga dalam menyikapi suatu keadaan. Menurut Kamus Besar Bahasa Indonesia (KBBI), emosi diartikan sebagai reaksi psikologis dan fisiologis yang menimbulkan perasaan bahagia, sedih takut dan sebagainya.

Akuntansi dalam rumah tangga sangat erat kaitannya dengan emosi yang dimiliki individu dalam mencapai tujuannya. Untuk itu, membahas akuntansi dalam rumah tangga harus dikaitkan dengan dimensi emosional, tidak hanya didasari pada pola fikir tapi juga oleh unsur-unsur akal sehat, nilai, keyakinan, dan emosi.

\section{Teori Mental Accounting}

Mental Accounting merupakan salah satu teori yang membahas prilaku individu dalam mengambil dan menyikapi keuangan individu atau rumah tangga. Thaler (1994) mendefinisikan mental accounting sebagai rangkaian operasi kognitif yang digunakan oleh individu atau rumah tangga dalam mengkode, membuat dan mengevaluasi kategori aktifitas finansialnya. "Mental accounting is the set of cognitive operations used by individuals and households to organize, evaluate, and keep track of financial activities" (Thaler, 1994).

Fokus teori mental accounting adalah bagaimana individu menyikapi dan mengevaluasi situasi terhadap kemungkinan yang memberikan dua hasil atau lebih. Dalam hal ini, individu mempunyai kecenderungan atau prilaku untuk mengelompokkan uang yang dimiliki berdasarkan sumber penerimaan uang dan berdasarkan kegunaan dari uang tersebut, seperti yang diungkapkan oleh Shefrin dan Thaler (1988):

"...report that people tend to decompose their income according to its source into three categories: salary income, asset income, and future income, and find that the marginal propensity to spend the income differs among these categories".

Teori mental accounting lahir dari pemikiran terhadap perilaku keuangan yang biasanya sering bertindak irrational, terlalu percaya diri terhadap pengetahuan, kemampuan yang dimiliki (overconfident) dan adanya ketidakpastian terhadap suatu ramalan (non bayes forecast). Sejalan dengan hal tersebut, setiap individu mempunyai frame sendiri dalam mengambil keputusannya, tergantung kepada penilaiannya terhadap suatu harta atau benda. Misalnya, seorang ibu rumah tangga beranggapan membeli sebuah buku seharga Rp. 100.000 sangat mahal sedangkan untuk membeli jaket Rp.150.000 dianggap normal. Hal itu tergantung dari penilaian ibu tersebut terhadap kedua asset tersebut. 
Komponen yang membangun mental accounting menurut Thaler (1999) terdiri atas tiga hal yang pertama, adanya presepsi terhadap hasil (outcome) serta membuat dan mengevaluasi keputusan, kedua menetapkan aktifitas untuk pencatatan yang lebih spesifik dan ketiga, menetukan batas atau periode evaluasi terhadap akun-akun dimana, ada yang dievaluasi mingguan, bulanan atau tahunan. Ketiga komponen tersebut mempengaruhi individu dalam bersikap dan mengambil keputusan.

\section{Kerangka Berpikir}

Kerangka berpikir penelitian ini dapat digambarkan sebagai berikut:

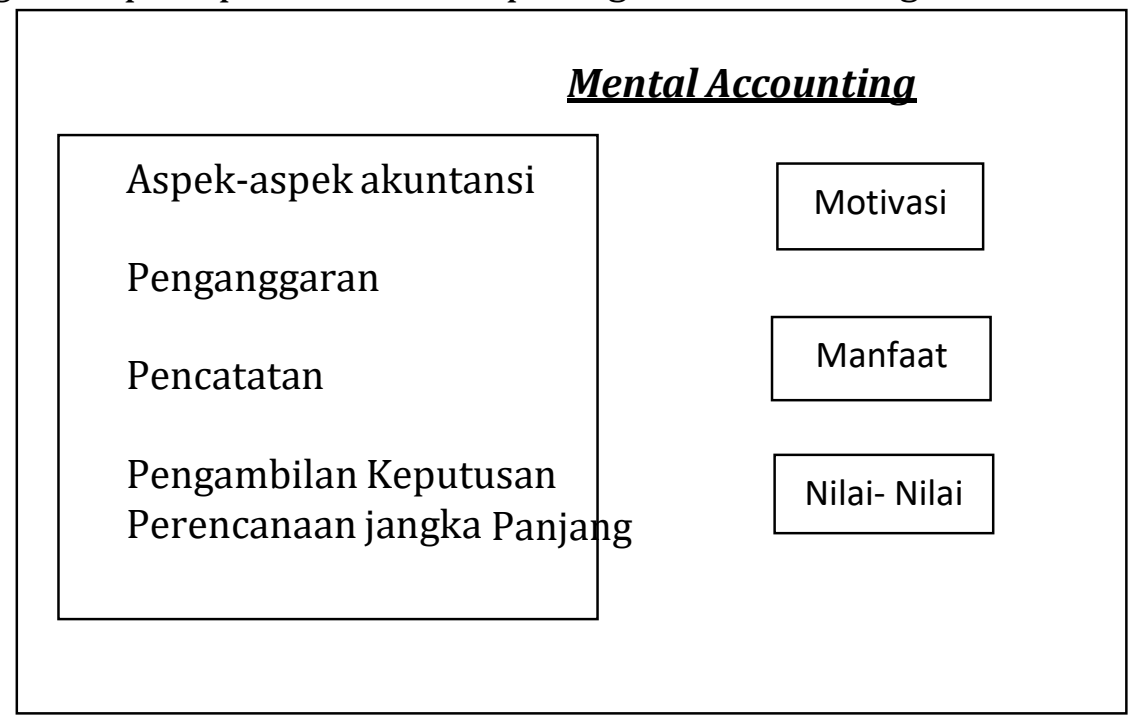

\section{Metodologi Penelitian}

Desain Penelitian, Penelitian ini didesain dengan menggunakan pendekatan fenomenologi yang bertujuan untuk mengetahui bagaimana akuntansi diterapkan dalam rumah tangga serta untuk memahami apa motif, manfaat dan nilai-nilai yang mendasari akuntansi dalam rumah tangga. Data yang digunakan pada penelitian ini adalah data primer, yaitu data yang diperoleh langsung dari pihak pertama, yang selanjutnya akan diolah sesuai kebutuhan dalam penelitian. Sumber data penelitian kualitatif adalah manusia selaku informan (narasumber) yang mempunyai informasi yang dibutuhkan oleh peneliti. Dalam penelitian ini data diperoleh dari informan yang dipilih sesuai kebutuhan dalam penelitian, yaitu yang masuk dalam kategori akuntan dan non akuntan serta telah menjalani kehidupan rumah tangga.

Teknik pengumpulan data dalam penelitian ini adalah dengan melakukan wawancara semi terstruktur dengan para informan sampai semua informasi yang dibutuhkan oleh peneliti terpenuhi. Wawancara semi terstruktur ini digunakan agar pembicaraan tetap terkontrol dan data yang diinginkan bisa disampaikan dengan pemaparan yang lebih jelas dan lengkap. Wawancara dalam penelitian ini tidak dilakukan dalam bentuk focus group melainkan secara berpasangan (suami istri) mengingat bahan yang akan diwawancarai adalah hal yang bersifat sensitife atau pribadi meliputi rahasia keuangan pasangan dalam rumah tangga. 
Penelitian ini dilakukan pada informan yang berlatar belakang akuntan baik itu akademisi maupun praktisi serta pada pasangan rumah tangga yang berlatar belakang non akuntan. Untuk akuntan akademisi peneliti memilih dosen yang mengajar di salah satu Perguruan Tinggi Negeri di kota Padang sebanyak dua orang beserta pasangannya. Sedangkan akuntan praktisi yang dipilih akuntan yang bekerja di Kantor Akuntan Publik (KAP) sebanyak dua orang beserta pasangannya. Selanjutnya non akuntan dipilih sebanyak empat orang beserta pasangannya yang berdomisili di Pasaman Barat. Adapun kriteria informan yang dipilih dalam penelitian ini adalah seseorang yang telah berkeluarga, baik itu berlatar belakang profesi akuntan maupun non akuntan dan bersedia diwawancarai dan memberikan informasi yang dibutuhkan peneliti. Dalam hal ini, kemudahan akses dan faktor kesedian untuk menjadi informan merupakan hal utama bagi peneliti untuk memilih suatu pasangan menjadi objek penelitian.

Tabel 1:

Informan

\begin{tabular}{|c|c|c|}
\hline No & Informan & Jumlah \\
\hline 1 & Akuntan Praktisi (Auditor) & 2 Orang (beserta pasangan) \\
\hline 2 & Akuntan Pendidik ( Dosen) & 2 Orang (beserta pasangan) \\
\hline 3 & Non Akuntan & 4 Orang (beserta pasangan) \\
\hline
\end{tabular}

Metode Analisis Data: Pendekatan Fenomenologi yang di mulai dengan menelaah seluruh data yang tersedia dari berbagai sumber, yaitu dari wawancara, pengamatan yang sudah dituliskan atau disimpan dalam catatan lapangan, alat perekam, dokumen pribadi informan, foto, dan sebagainya. Setelah dibaca, dipelajari, dan ditelaah, langkah berikutnya adalah mengadakan reduksi data yang dilakukan dengan jalan melakukan abstraksi. Tahap akhir dari analisis data ini ialah mengadakan pemeriksaan keabsahan data. Setelah selesai tahap ini, mulailah kini tahap penafsiran data dalam mengolah hasil sementara menjadi teori substantif dengan menggunakan beberapa metode tertentu.

\section{Hasil Penelitian Dan Pembahasan}

Adapun hasil dan pembahasan dari penelitian ini adalah sebagai berikut:

Keluarga informan pada penelitian ini, terdiri dari akuntan dan non akuntan yang merupakan Pegawai Negeri Sipil dan wirasawsta. Motivasi penerapan praktik akuntansi dalam keluarga akuntan adalah keinginan untuk terbebas dari hutang, untuk meredam motif konsumtif, menikmati hidup dan karena dipengaruhi faktor pekerjaan. Motivasi yang masih senada juga menjadi dorongan keluarga non akuntan dalam menerapkan praktik akuntansi diantaranya untuk mendapatkan kenyamanan, adanya kekhawatiran terhadap hutang dan keinginan mendapatkan kerukunan dalam rumah tangga. 
Tabel 2. Motivasi Penerapan praktik akuntansi

\begin{tabular}{|l|l|l|l|}
\hline $\begin{array}{c}\text { Akuntan } \\
\text { Pendidik PNS }\end{array}$ & $\begin{array}{c}\text { Pasangan Akuntan } \\
\text { Praktisi PNS }\end{array}$ & $\begin{array}{c}\text { Pasangan Akuntan } \\
\text { Praktisi Non PNS }\end{array}$ & $\begin{array}{c}\text { Non Akuntan PNS } \\
\text { dan Non PNS }\end{array}$ \\
\hline $\begin{array}{c}\text {-Uang } \\
\text { merupakan hal } \\
\text { yang sensitife, } \\
\text {-Adanya } \\
\text { perasaan takut } \\
\text { terjebak hutang }\end{array}$ & $\begin{array}{c}\text {-Menghindari rasa } \\
\text { panik, was-was } \\
\text {-Karena pengaruh } \\
\text { dari faktor kerjaan }\end{array}$ & $\begin{array}{l}\text {-Untuk Meredam } \\
\text { motiv konsumtif }\end{array}$ & $\begin{array}{l}\text {-Untuk mencipatakan } \\
\text { rasa damai, rasa cinta, } \\
\text {-Supaya tidak saling } \\
\text { menyalahkan } \\
\text {-Keinginan untuk bisa } \\
\text { sama dengan } \\
\text { pasangan lain }\end{array}$ \\
\hline
\end{tabular}

Oleh karena itu, manfaat yang dirasakan oleh keluarga akuntan dan non akuntan dalam menerapkan akuntansi di rumah tangga menunjukkan hal yang senada yaitu bermuara pada kenikmatan hidup dan kenyamanan. Selain itu, manfaat yang didapatkan oleh keluarga akuntan dan non akuntan dalam menerapkan akuntansi dalam rumah tangga adalah menghilangkan rasa was-was, kepanikan sekaligus dapat meningkatkan kerukunan dan menyenangkan hati pasangan dalam rumah tangga. Adapun nilai-nilai yang lahir dari penerapan akuntansi dalam keluarga akuntan dan non akuntan adalah terbentuknya sikap saling percaya, disiplin, jujur, terbuka dan bertanggung jawab.

Tabel 3. Manfaat Praktik Akuntansi dalam Rumah

Tangga

\begin{tabular}{|l|}
\hline \multicolumn{1}{|c|}{ Keluarga Akuntan dan Non Akuntan } \\
\hline - Mendapatkan kepuasan bathin, kenyamanan \\
- Meningkatkan kerukunan pasangan dalam rumah tangga \\
- Merasa dihargai pasangan \\
- Dapat menikmati hidup \\
- Meningkatkan rasa cinta \\
-Dapat menghandle kebutuhan yang mendesak \\
\end{tabular}

Praktik akuntansi dalam rumah tangga keluarga akuntan dan non akuntan terhadap berbagai aspek akuntansi yang diidentifikasi. Pada aspek penganggaran dapat dikatakan telah tersistem dengan baik. Akan tetapi, ada keluarga akuntan pendidik yang tidak menganggarkan penggunaan keuangannya hanya fokus digunakan sesuai kebutuhan saja. Kemudian, penganggaran pada keluarga non akuntan yang merupakan Pegawai Negeri Sipil juga telah dianggarkan berdasarkan alokasi penggunaan sedangkan keluarga non akuntan yang wirasawsta tidak mempunyai anggaran, hanya menggunakan sesuai kebutuhan.

Tabel 4. Praktik Penganggaran dalam Rumah Tangga 


\begin{tabular}{|c|c|c|c|}
\hline Akuntan Pendidik & $\begin{array}{c}\text { Pasangan } \\
\text { Akuntan } \\
\text { Prakti }\end{array}$ & Non Akuntan PNS & $\begin{array}{c}\text { Non Akuntan } \\
\text { Wiraswasta }\end{array}$ \\
\hline $\begin{array}{l}\text {-Lebih sistematis dan } \\
\text { jelas } \\
\text {-Lebih } \\
\text { memperhatikan } \\
\text { anggaran rumah } \\
\text { tangga } \\
\text {-Pembagian } \\
\text { penggunaan dana } \\
\text { anggaran sesuai } \\
\text { dengan tujuan dan } \\
\text { sumber pendapatan } \\
\text { dana }\end{array}$ & $\begin{array}{l}\text {-Lebih sistematis, jelas } \\
\text {-Pemanfaatan } \\
\text { dana sesuai } \\
\text { tujuan dan } \\
\text { sumber dana }\end{array}$ & $\begin{array}{l}\text {-Lebih } \\
\text { memperhatikan } \\
\text { anggaran rumah } \\
\text { tangga } \\
\text {-Pembagian sumber } \\
\text { dana anggaran sesuai } \\
\text { tujuan } \\
\text {-Perlakuan terhadap } \\
\text { pendapatan tidak } \\
\text { tetap sama }\end{array}$ & $\begin{array}{l}\text {-Tidak ada } \\
\text { anggaran yang } \\
\text { terlalu } \\
\text { dipastikan- } \\
\text {-Penggunaan } \\
\text { sesuai } \\
\text { kebutuhan }\end{array}$ \\
\hline
\end{tabular}

Keluarga akuntan pendidik dan praktisi pada aspek pencatatan, terdapat akuntan pendidik yang mencatat pengeluaran secara namun tidak rutin dan ada yang tidak mencatat pengeluaran. Sedangkan akuntan praktisi, ada keluarga yang rutin menulis pengeluaran dan keluarga yang tidak mencatat pengeluaran. Berbeda dengan keluarga non akuntan yang merupakan Pegawai Negeri Sipil dimana, semua keluarga informan yang non akuntan dan merupakan Pegawai Negeri Sipil membuat catatan secara rutin terhadap pengeluarannya. Hanya, keluarga informan yang non akuntan yang berwiraswata yang tidak mencatat pengeluaran.

Tabel 5. Praktik Pencatatan dalam Rumah Tangga

\begin{tabular}{|c|c|c|c|c|}
\hline $\begin{array}{l}\text { Akuntan } \\
\text { Pendidik PNS }\end{array}$ & $\begin{array}{c}\text { Pasangan } \\
\text { Akuntan } \\
\text { Praktisi PNS }\end{array}$ & $\begin{array}{l}\text { Pasangan } \\
\text { Akuntan } \\
\text { Praktisi Non PNS }\end{array}$ & $\begin{array}{c}\text { Non Akuntan } \\
\text { PNS }\end{array}$ & $\begin{array}{c}\text { Non Akuntan } \\
\text { Wiraswasta }\end{array}$ \\
\hline $\begin{array}{l}\text {-Tidak membuat } \\
\text { catatan } \\
\text {-Kadang-kadang } \\
\text { mencatat } \\
\text {-Review melalui } \\
\text { komunikasi }\end{array}$ & $\begin{array}{l}\text {-Mencatat } \\
\text { Pengeluaran } \\
\text {-Mencek } \\
\text { saldo } \\
\text { printnan } \\
\text { bank }\end{array}$ & $\begin{array}{l}\text {-Tidak Mencatat } \\
\text {-Komunikasi } \\
\text { dengan } \\
\text { pasangan } \\
\text { terhadap } \\
\text { pengeluaran }\end{array}$ & $\begin{array}{l}\text {-Mencatat } \\
\text { pengeluaran secara } \\
\text { rutin, } \\
\text {-membuat list belanja } \\
\text { mingguan } \\
\text {-mencatat alokasi gaji }\end{array}$ & $\begin{array}{l}\text {-Tidak } \\
\text { membuat } \\
\text { catatan }\end{array}$ \\
\hline
\end{tabular}

Pada sisi pengambilan keputusan, dalam hal tabungan semua keluarga akuntan rutin melakukannya. Kemudian, pengambilan keputusan untuk pengeluaran yang besar, keseluruhan keluarga akuntan setuju untuk memilih membeli secara angsuran meskipun mempunyai dana yang cukup. Pengambilan keputusan pada keluarga non akuntan, untuk pilihan menyimpan didominasi dalam bentuk usaha yang produktif sedangkan untuk keputusan pembelian yang besar juga sependapat dengan keluarga akuntan. 
Tabel 6. Pengambilan Keputusan dalam Rumah Tangga

\begin{tabular}{|c|c|c|c|}
\hline Aspek & $\begin{array}{l}\text { Akuntan } \\
\text { Pendidik PNS }\end{array}$ & $\begin{array}{c}\text { Pasangan Akuntan } \\
\text { Praktisi PNS dan Non PNS }\end{array}$ & $\begin{array}{c}\text { Non Akuntan } \\
\text { PNS dan Non PNS }\end{array}$ \\
\hline Menabung & $\begin{array}{l}\text {-Bentuk simpanan } \\
\text { tunai dan benda, } \\
\text {-Tunai untuk } \\
\text { tambahan } \\
\text { konsumsi } \\
\text {-Bentuk benda } \\
\text { untuk simpanan } \\
\text { jangka panjang }\end{array}$ & $\begin{array}{l}\text {-Sumber simpanan } \\
\text { pendapatan tetap dan } \\
\text { tidak tetap } \\
\text {-tabungan dalam } \\
\text { bentuk tunai untuk } \\
\text { simpanan jangka } \\
\text { panjang }\end{array}$ & $\begin{array}{l}\text {-Sumber simpanan } \\
\text { dalam bentuk usaha } \\
\text { produktif }\end{array}$ \\
\hline $\begin{array}{l}\text { Pengeluaran } \\
\text { yang } \\
\text { sifatnya } \\
\text { besar }\end{array}$ & $\begin{array}{l}\text {-Hutang hal yang } \\
\text { wajar untuk } \\
\text { pengeluaran yang } \\
\text { non konsumtif }\end{array}$ & $\begin{array}{l}\text {-Mempertimbangkan } \\
\text { kemampuan } \\
\text { membayar } \\
\text { - Hutang memberatkan } \\
\text { untuk non konsumtif bisa } \\
\text { dipertimbangkan }\end{array}$ & $\begin{array}{l}\text {-Hutang merupakan } \\
\text { hal wajar untuk non } \\
\text { konsumtif, } \\
\text {-angsuran } \\
\text { merupakan pilihan } \\
\text { meskipun dalam } \\
\text { kondisi keuangan } \\
\text { financial yang } \\
\text { mendukung }\end{array}$ \\
\hline
\end{tabular}

Pada sisi perencanaan jangka panjang, keluarga akuntan lebih memilih berinvestasi yang sifatnya menyimpan dalam bentuk benda berupa emas, dan hanya satu keluarga akuntan yang memilih menyimpan dalam bentuk tunai. Sedangkan keluarga non akuntan dominan merencanakan jangka panjang melalui investasi pada perkebunan sawit dan peternakan.

Tabel 7. Perencanaan Keuangan Jangka Panjang dalam Rumah Tangga

\begin{tabular}{|l|l|l|l|c|}
\hline $\begin{array}{l}\text { Akuntan } \\
\text { Pendidik } \\
\text { PNS }\end{array}$ & $\begin{array}{l}\text { Pasangan Akuntan } \\
\text { Praktisi PNS }\end{array}$ & $\begin{array}{l}\text { Pasangan } \\
\text { Akuntan } \\
\text { Praktisi Non PNS }\end{array}$ & $\begin{array}{c}\text { Non Akuntan } \\
\text { PNS }\end{array}$ & $\begin{array}{c}\text { Non Akuntan } \\
\text { Wiraswasta }\end{array}$ \\
\hline
\end{tabular}




\begin{tabular}{|l|l|l|l|l|}
\hline -Sumber & -Menyukai & -Lebih memilih & -Penjaminan Sk, & -Dengan \\
Pendanaanny & simpanan tunai dibank & untuk & untuk & menginvestasikan \\
a dalam & dan & menyimpan & berinvestasi & pada emas dan \\
bentuk & investasi dalam & dalam bentuk & pada kebun & penambahan modal \\
simpanan & bentuk usaha & emas & sawit, & barang eleketronik \\
emas, & produktif dan & melalui kerjasama & dan peternakan & \\
deposito, & -tabungan pendidikan & dengan salah satu & & \\
obligasi & untuk anak & bank syariah & & \\
& & & & \\
& & & & \\
& & & \\
\hline
\end{tabular}

\section{Kesimpulan Dan Saran}

Berdasarkan hasil penelitian yang telah dilakukan, maka dapat ditarik kesimpulan (1) dilihat dari Motivasi. Motivasi yang mempengaruhi informan mempraktikkan akuntansi bermuara pada pencapaian kenikmatan hidup. Sementara itu, manfaat yang diperoleh informan selama menerapkan praktik akuntansi dalam rumah tangga yaitu, terpenuhinya kepuasan bathin dan terciptanya kerukunan dalam rumah tangga. Kemudian, nilai-nilai yang lahir dari praktik akuntansi dalam rumah tangga adalah nilai-nilai yang positif seperti tanggung jawab, disiplin, keterbukaan, amanah, saling menghargai dan sikap jujur. (2) Dilihat dari aspek penganggararan. Ada tiga tipe penganggaran yang dilakukan oleh pasangan keluarga informan, yaitu penganggaran yang bersifat sistematis, penganggaran yang hanya berdasarkan anggaran rutin, dan informan yang tidak membuat penganggaran. Terkait pencatatan, sebagian informan menyukai melakukan pencatatan terhadap pengeluaran secara tertulis dan bahkan rutin dilakukan dan sebagian informan lainnya lebih nyaman dengan mengingatnya saja dalam pikiran tanpa memerlukan sebuah catatan pengeluaran. (3) Selanjutnya pengambilan keputusan. Dari aspek ini peneliti menginvestigasi dua hal, pertama, keputusan menabung kedua, pengeluaran yang sifatnya besar. Hampir semua pasangan dalam rumah tangga selalu menyediakan tabungan baik dalam bentuk tunai maupun dalam bentuk benda. Hal ini bertujuan untuk spekulasi terhadap peristiwa yang tidak diduga dan juga untuk investasi dalam memenuhi tujuan jangka panjang. Selanjutnya, terhadap pengeluaran yang besar informan lebih memilih untuk membeli secara angsuran atau cicilan dengan tetap mempertimbangkan kemampuan membayar sehingga, tidak ada perasaan terlillit hutang. Terkait dengan aspek perencanaan jangka panjang, keluarga akuntan cenderung investasi dalam bentuk benda dan keluarga non akuntan lebih memilih investasi dalam bentuk usaha yang bersifat produktif.

Fenomena akuntansi dalam rumah tangga yang dilakukan oleh delapan pasangan keluarga pada beberapa aspek terdapat perbedaan. Perbedaan praktik akuntansi dalam rumah tangga tersebut dilatarbelakangi oleh tingkat pengetahuan dan pemahaman yang dimiliki terhadap akuntansi. Selain itu, perbedaan tersebut juga ditentukan oleh unsur geografis dan status pekerjaan yang dimiliki. Akan tetapi, meskipun individu atau pasangan keluarga tersebut mempunyai background pendidikan akuntansi pada beberapa aspek menunjukkan perilaku yang tidak sesuai dengan pendidkan yang dimiliki. Perilaku yang tidak sesuai dengan pendidikan yang dimiliki tersebut, disebabkan karena ada hal lain yang menjadi pertimbangan dalam 
berperilaku dan mengambil keputusan. Hal tersebut merupakan dorongan emosional yang ditentukan oleh mental yang dimiliki masing-masing individu. Dalam perspektif mental accounting perilaku individu yang berbeda tersebut ditentukan dari hasil penilaian, pengelompokan (categorize) dan hasil evaluasi (evaluated) setiap individu yang berbeda-beda terhadap kondisi dan permasalahan.

Penelitian ini mempunyai beberapa keterbatasan, maka berdasarkan keterbatasan tersebut diberikan saran sebagai berikut: Peneliti selanjutnya sebaiknya memilih informan yang lebih bervariatif baik dari segi background pendidikan, status pekerjaan maupun dari sisi kebudayan dan unsur geografis. Peneliti sebaiknya melakukan wawancara dengan durasi yang lebih lama, sehingga fenomena akuntansi dalam rumah tangga yang didapatkan tidak sebatas kulit luarnya saja namun lebih dalam dan kompleks. Selain itu, peneliti selanjutnya juga bisa mengkaji akuntansi dalam rumah tangga dari perspektif budaya, seperti budaya matrilineal dalam minang kabau. Dan untuk pasangan rumah tangga sebaiknya, menerapkan praktik akuntansi dalam kehidupan rumah tangga.

\section{Referensi}

Carnegie, Garry D, Stephen P.W. (2005). "Household Accounting In Australia: Prescription and practice from the 1820s to the 1960s", Accounting, Auditing \& Accountability Journal. Vol. 20 Iss 2 pp. 210 - 236

Cresswell, Jhon W. (1998). Qualitative Inquiry And Research Design Choosing Among

Five

Tradition. London: Sage

De Bont, Werner dan Thaler. (1994). Financial Decision MakingIn Market and Firm: Behavorial Prespective. National Bureau Of Economic Research. No. 4777

Espa,Vitriya. Iwan Triyuwono dan Unti Ludigdo. (2011). "Konstruksi Bentuk Akuntansi Keluarga (Pendekatan Hipnometodologi), Skripsi

Hajaroh, Mami. (2011). Paradigma Pendekatan dan Metode Penelitian fenomenologi. Herdiansyah, Haris. 2011. Metodologi Penelitian Kualitatif, Untuk Ilmu Ilmu sosial. Jakarta: Salemba Empat

Manurung, DTH. Sinton, J. 2013. "Urgensi Peran Akuntansi Dalam Rumah Tangga (Studi Fenomenologis Pada Dosen - Dosen Akuntansi di Universitas Widyatama Bandung) jurnal Ilmiah Akuntansi dan Humanika Vol.3.No.Issn 2089-3310

Northcott, Deryl dan Dollin. 2000,"Home Accountants: Exploring Their Practices". University of Manchester School of Accounting And Finance . Accounting, Auditing \& Accountability Journal. Vol .13 Iss 4 pp 475 - . 501

Phal, J. 2000. "Couples And Their Money: Patterns Of Accounting And Accountability In The Domestic Economy". Accounting, Auditing \& Accountability Journal . Vol 13 Iss 4 pp $502-. .517$ 